【論文】

\title{
強震地震動の非定常スペクトル特性とその波動論的考察* \\ NONSTATIONARY CHARACTERISTICS AND WAVE INTERPRETATION OF STRONG EARTHQUAKE GROUND MOTIONS
}

\author{
神山 真** \\ By Makoto KAMIYAMA
}

\section{1.まえがき}

一般に土木構造物は道路，鉄道，パイプラインなどに 例をとるまでもなく一方向に長い構造物が多い。また， 近年, 長大スパン橋, 大ダムなど長大構造物が次第に建 設されつつあるが，これらの長大構造物は一般に平面的 ひろがりをもつ構造物としてとらえることができる。

このように一方向に長いか，あるいは平面的ひろがり をもつ構造物の地震時挙動は一般の小建築物のような単 体として扱える構造物のそれとは異なるものと考えられ る. 特に,このような構造物は各点に異なった位相をも たらすような入力地震に対しては不利に応答すると考え られる.したがって，土木構造物のように一方向に長い か，または平面的ひろがりをもつ構造物の耐震設計に際 しては, 入力地震動の波動特性についての基礎的考察が きわめて重要になってくると思われる.また，構造物を 支持するところの地盤も広い意味での平面的ひろがりを もつ構造物と考えられ, 砂地盤の液状化などの地盤の耐 震的検討にとっても地盤中を伝播する地震波動特性は重 要であると思われる．筆者は地震時における地盤内の応 力, ひずみの評価に関連して, 地盤中に位相差をもたら して平面的に伝播する表面波は工学的に危険であること を指摘した ${ }^{2)}$.

ところで, 地震波動の伝播特性を知るには地震観測記 録が不可欠であるが，地震波動特性は軽震時々強震時は 異なるものと予想されるので，特に震害をもたらすよう な巨大地震の強震記録が重要となってくる. 近年, 日本 においても強震計の充実がはかられ，強震記録が次第に 集積されつつあるが，これらの強震記録は構造物の耐震 設計の際の入力地震として有効であるのみならず，地震

\footnotetext{
* 土木学会第 13 回地震工学研究発表会 ${ }^{1)}$ (昭和 49 年 7 月) な どで発表した一部にその後の考察を加えたものである。

** 正会員 工修 東北工業大学助教授 工学部土木工学科
}

の発震機構, 地震波動の伝播特性など種々の情報を提供 するきわめて貴重なものである.

一般に強震記録には種々の原因に由来すると思われる スペクトルの非定常性が一見して観察されるものが多 く, 強震記録の解釈に関連してスペクトルの非定常解析 法が最近，多く論じられるようになってきた.これま で，強震記録への応用を含めた非定常確率過程のスペク トルについてはすでにいくつかの定義が提案されている が，体系的に統一されておらず，目的に応じて解析手法 を用いているのが実情のよらである ${ }^{3)}$.しかし，いずれ の解析法を用いるにしても強震記録の非定常スペクトル 特性には震源からの地震エネルギーの放出過程, 地震波 動特性, 地款および地盤構造など多くの情報が隠されて いるのは確実であるので，これらの情報をもっとも有効 に抽出する手法を目的に応じて採用するのが適切と考え られる。

上述のような地震記録の非定常スペクトル特性を解析 して地震波動特性を考察した研究はすでにいくつかあ

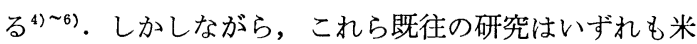
国で得られた強震記録を利用したものや周期数 10 秒の 波動をおもに地震学の観点から論じたものなどであり， そのまま直接に我国の強震記録の解釈や耐震工学的な目 的に応用するには問題があると考えられる. 特に，わが 国特有の沖積平野にみられる表層軟弱地盤の性質や日本 近海の巨大地震の特徵を考えると, 日本国内での巨大地 震の強震記録に即した，しかも耐震工学で問題となる周 期帯域（せいぜい周期 0.1 秒から 10 秒程度）での地震 波動特性についての考察の必要性が痛感される.

以上の観点から，この論文では波動論的立場から強震 記録を解釈するのに有効な非定常スペクトル解析の一手 法を述べるとともに，わが国で得られた代表的な強震記 録にその非定常スペクトル解析を施した，そして，それ らの解析結果にみられる非定常スペクトルの規則性に着 目し，これを強震記録が得られた地点付近の地盤構造を 
考虑した地震波伝播特性の面から考察した. 特に, この 論文では強震記録にみられる非定常スペクトルの規則性 を，表面波が表層地盤を伝播する際の分散現象に起因す るものとしてとらえ，この解釈の妥当性をモデル地盤に おける表面波 (Love 波) の伝播理論によるシミュレー ション計算で確かめた. さらに, これらの結果を総合し て, 平面的ひろがりをもつ構造物への入力地震波として の表面波の重要性について言及した.

\section{2. 非定常スペクトル解析}

上述したように非定常確率過程のスペクトル解析には これまでいくつかの定義が提案されている.これらはそ れぞれ一長一短を有するよらであるが，物理的解釈が容 易で，しかも理解しやすい定義としては Priestley?)の Evolutionary Power Spectrum や Mark ${ }^{8)}$ の Physical Spectrum などがあげられよう．最近では，これらの定 義をさらに発展させた研究もなされている.たとえば亀 田9 は Priestley の Evolutionary Power Spectrum の 概念を線形 1 自由度系の応答全エネルギーへ応用し, 非 定常パワースペクトルの算出を詳細に論じている.ま た, 星谷ら ${ }^{10)}$ むark の Physical Spectrum を発展さ せて非定常スペクトルの特性を組織的に論じている.

これらはいずれも定常確率過程で一義的に定義される パワースペクトルを非定常確率過程に拡張しょうとした ものであり, その定義の前提には地震動を非定常確率過 程としてモデル化しよ5とする意図があるように思われ る. 一方, 現象を確定的に扱うことによる非定常スペク トル解析を行い, 特定の地震動の発震機構や地震波の伝 播特性を明らかにしようとする手法も考えられる. 本研 究後者の手法に属する.もちろん, 確定関数を確率過 程でとらえなおせば，両者は共通の概念に到達する.

以下で述べる非定常スペクトル解析は Papoulis ${ }^{11)}$ の 著書などで知られるシステム論に㧍けるマルチ・フィル ターリングの原理を強震記録解析に応用したものである が, 結果的には筆者が後に知った Dziewonskiら ${ }^{4)}$ の方 法と同様な手法になった. 以下では Dziewonski らも考 察してない本解析手法の物理的意味について特に言及し ながら, 解析手法の大要を述べる.

\section{（1） マルチ・フィルターによる非定常スペクトル解 析}

いま，図一1 に示すように信号 $f(t)$ を異なるシステ 么関数を有する並列な帯域フィルターに同時に入力する とする.たとえば，図一2 のような中心円振動数 $\omega_{n}$ で 対称なシステム関数 $H_{n}(\omega)$ なる帯域通過フィルターを 考える.この帯域通過フィルターのインパルス応答 $h_{n}$

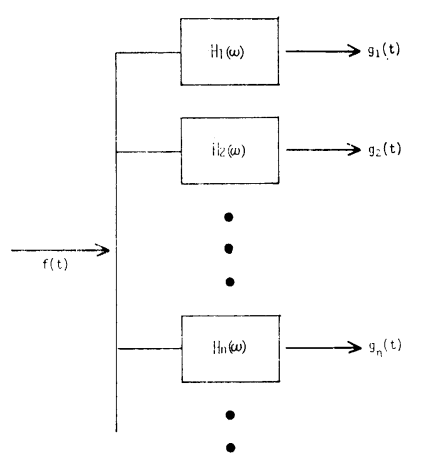

図-1 マルチ・フィルター

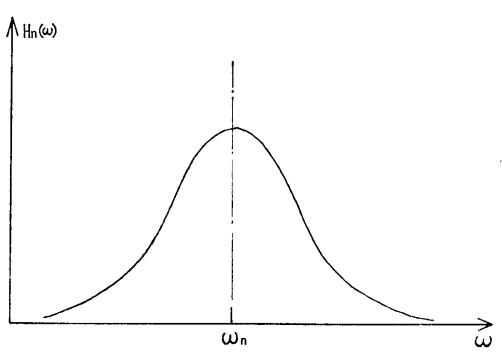

图一2 帯域通過フィルター

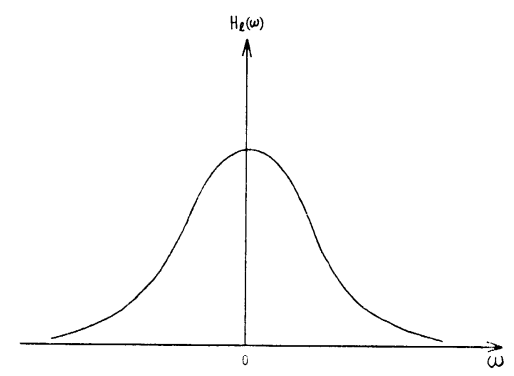

図一3 等価低域通過フィルター

( $t$ ） は次のようになる.

$$
\begin{aligned}
& h_{n}(t)=\frac{1}{2 \pi} \int_{-\infty}^{\infty} H_{n}(\omega) e^{i \omega t} d \omega \\
& =h_{e}(t) e^{i \omega_{n} t}
\end{aligned}
$$

ここに, $t:$ 時間, $\omega:$ 円振動数.

ただし，式 (2)の $h_{l}(t)$ は 図一3 に示すような 図一2 の帯域通過フィルター $H_{n}(\omega)$ を左に $\omega_{n}$ だけ移動させ た原点 $(\omega=0)$ に中心円振動数をもつ等価低域通過フィ ルターとよばれるフィルター $H_{l}(\omega)$ のインパルス応答 である.

すると，図一2 の帯域通過フィルターに信号 $f(t)$ を 入力したときの出力 $g_{n}(t)$ は次のように表わされる.

$$
g_{n}(t)=\int_{-\infty}^{\infty} f(\tau) h_{n}(t-\tau) d \tau
$$

式（3）は式（2）加次の上うに変形される.

$$
\begin{aligned}
& g_{n}(t)=\left|\int_{-\infty}^{\infty} f(\tau) h_{l}(t-\tau) e^{-i \omega_{n} \tau} d \tau\right| \\
& \cdot e^{i\left[\omega_{n} t+\varphi\left(\omega_{n}, t\right)\right\}}
\end{aligned}
$$


ここに,

$$
\varphi\left(\omega_{n}, t\right)=\tan ^{-1}\left[\frac{I_{m}\left\{\int_{-\infty}^{\infty} f(\tau) h_{l}(l-\tau) e^{-i \omega_{n} \tau} d \tau\right\}}{R_{e}\left\{\int_{-\infty}^{\infty} f(\tau) h_{l}(t-\tau) e^{-i \omega_{n} \tau} d \tau\right\}}\right]
$$

式 (4) のように帯域通過フィルター $H_{n}(\omega)$ の出力 $g_{n}$ ( $t$ ）は振幅および位相ともに変調された信号となるが, 同式を視察すれば明らかなよらに，出力 $g_{n}(t)$ の振幅 包絡線

$$
\left|\int_{-\infty}^{\infty} f(\tau) h_{l}(t-\tau) e^{-i \omega_{n} \tau} d \tau\right|
$$

は信号 $f(\tau) \cdot h_{l}(t-\tau)$ のフーリエ・スペクトルの円振 動数 $\omega_{n}$ 成分に等しいことがわかる. したがって, 信号 $f(t)$ に含まれる非定常スペクトル特性の $\omega_{n}$ 成分の時 間的変動は原信号 $f(t)$ に一種のウィンドー関数 $h_{l}(t-$ $\tau)$ をかけた形で, 出力 $g_{n}(t)$ の振幅包絡線の時間変動 として求めることができる. いま, 出力 $g_{n}(t)$ の振幅 包絡線の式に含まれる帯域通過フィルター $H_{n}(\omega)$ の中 心円振動数 $\omega_{n}$ を $\omega$ と一般化して, 次式のように表わ し, 以下ではこれを瞬間フーリェ・スペクトル (Instantaneous Fourier Spectrum) とよぶことにする.

$$
F(\omega, t)=\left|\int_{-\infty}^{\infty} f(\tau) h_{l}(t-\tau) e^{-i \omega \tau} d \tau\right|
$$

\section{(2) 瞬間フーリエ・スペクトル $\boldsymbol{F}(\boldsymbol{\omega}, \boldsymbol{t})$ の 物理的 意味}

式 (6) で定義した瞬間フーリエ・スペクトル $F(\omega, t)$ は原信号 $f(t)$ が 0 から $T$ までの継続時間をもつとす れば, 次式のように表わされる.

$$
\begin{aligned}
F(\omega, t)= & \frac{\sqrt{\left\{\int_{0}^{T} f(u) h_{l}(t-u) \cos \omega u d u\right\}^{2}}}{+\left\{\int_{0}^{T} f(u) h_{l}(t-u) \sin \omega u d u\right\}^{2}}
\end{aligned}
$$

一方， $f(t)$ を入力加速度とする線形 1 自由度系の運 動方程式は周知のように次式で与えられる.

$$
\ddot{y}(t)+2 h_{0} \omega_{0} \dot{y}(t)+\omega_{0}^{2} y(t)=-f(t)
$$

ここに, $y(t)$ は質点の相対変位, $h_{0}, \omega_{0}$ はおおお減 衰定数, 固有円振動数である.

ここで, 減衰定数 $h_{0}=0$ の非隇衰 1 質点系を考え, さらに入力加速度としてパラィーターてによって支配 される次の上らな時系列 $f(l, \tau)$ を考える.

$$
f(t, \tau)=f(t) \cdot r(\tau-t)
$$

ここに, $f(t)$ は人力加速度, $r(\tau-t)$ はウィンドー関 数である.

すると, 式 (8) の質点の相対変位 $y(t)$, 相対速度 $\dot{y}$ ( $t$ ) は時間 $t$ のほかにパラメーターてによって支配さ れる時系列 $y(t, \tau), \dot{y}(t, \tau)$ としてそれぞれ次の上うに
表わされる.

$$
\begin{array}{r}
y(t, \tau)=-\frac{1}{\omega_{0}} \int_{0}^{t} f(u) \cdot r(\tau-u) \sin \omega_{0}(t-u) d u \\
\ldots \ldots \ldots \ldots \ldots \ldots \ldots \ldots \ldots \ldots \ldots \ldots \ldots \ldots \ldots \ldots \ldots \\
\dot{y}(t, \tau)=-\int_{0}^{t} f(u) \cdot r(\tau-u) \cos \omega_{0}(t-u) d u
\end{array}
$$

いま, 式 (10), (11) の質点変位, 質点速度について 残留振動（入力加速度終了後の質点系の振動）を考え る. 残留振動の始めを改めて $t=0$ とすると, 残留振動 の質点変位 $y_{r}(t, \tau)$, 質点速度 $\dot{y}_{r}(t, \tau)$ はそれぞれ次 のように表わされる.

$$
\begin{aligned}
& y_{r}(t, \tau)=C_{1}\left(\tau, \omega_{0}\right) \cos \omega_{0} t+C_{2}\left(\tau, \omega_{0}\right) \sin \omega_{0} t \\
& \dot{y}_{r}(t, \tau)=-C_{1}\left(\tau, \omega_{0}\right) \omega_{0} \sin \omega_{0} t \\
& +C_{2}\left(\tau, \omega_{0}\right) \omega_{0} \cos \omega_{0} t
\end{aligned}
$$

ここに,

$$
\begin{gathered}
C_{1}\left(\tau, \omega_{0}\right)=-\frac{1}{\omega_{0}} \int_{0}^{T} f(u) r(\tau-u) \sin \omega_{0}(T-u) d u \\
\ldots \ldots \ldots \ldots \ldots \ldots \ldots \ldots \ldots \ldots \ldots \ldots \ldots \ldots \ldots \ldots \ldots \\
C_{2}\left(\tau, \omega_{0}\right)=-\frac{1}{\omega_{0}} \int_{0}^{T} f(u) r(\tau-u) \cos \omega_{0}(T-u) d u
\end{gathered}
$$

ただし, 入力加速度の継続時間は $u=0$ から $u=T$ ま でとしている.

式 (13) （15） から残留振動の質点速度の絶対值 $\left|\dot{y}_{r}(t, \tau)\right|$ は次のように与えられる.

$$
\begin{aligned}
\left|\dot{y}_{r}(t, \tau)\right|= & \sqrt{\left\{\int_{0}^{T} f(u) r(\tau-u) \cos \omega_{0} u d u\right\}^{2}} \\
& +\left\{\int_{0}^{T} f(u) r(\tau-u) \sin \omega_{0} u d u\right\}^{2}
\end{aligned}
$$

ここで, 式 (16) の $\left|\dot{y}_{r}(t, \tau)\right|$ は $\omega_{0}$ と $\tau$ のみの関数 となるから, ウィンドー関数 $r(\tau-u)$ の移動時間長 $\tau$ を改めて $\tau=t$ と置換して, 次のように $V\left(\omega_{0}, t\right)$ と表 わす。

$$
\begin{aligned}
V\left(\omega_{0}, t\right)= & \frac{\sqrt{\left\{\int_{0}^{T} f(u) r(t-u) \cos \omega_{0} u d u\right\}^{2}}}{+\left\{\int_{0}^{T} f(u) r(t-u) \sin \omega_{0} u d u\right\}^{2}}
\end{aligned}
$$

式 (17) から固有円振動数 $\omega_{0} を も つ$ 非減衰質点系の残 留振動の質点速度の絶対振幅すなわち残留振動の速度心 答スペクトルの $\omega_{0}$ 成分はウィンドー関数 $r(t-u)$ を等 価低域フィルターのインパルス応答 $h_{l}(t-u)$ と同一に 選べば, 式 (7) の瞬閒フーリエ・スペクトル $F(\omega, t)$ の $\omega_{0}$ 成分とまったく同一であることがわかる、いいかえ れば，瞬間フーリエ・スペクトル $F(\omega, t)$ は信号 $f(u)$ を $u=t$ の近傍でウィンドー関数 $h_{l}(u)$ をかけて漏波 
した信号の非減衰 1 質点系の残留速度応答スペクトルの 強度という形で原信号 $f(u)$ に含まれる時間 $u=t$ での 非定常スペクトル特性を表わそうとしたものであること がわかる。

\section{（3）瞬間フーリエ・スペクトルの算出とフィルター の選択}

上述のように信号 $f(t)$ の瞬間フーリエ・スペクトル $F(\omega, t)$ を帯域通過フィルター $H_{n}(\omega)$ へ $f(t)$ を入力 したときの出力 $g_{n}(t)$ の振幅包絡線として定義した. い ま, $f(t), g_{n}(t)$ のフーリエ変換をそれぞれ $F_{0}(\omega), G_{n}$ ( $\omega)$ とすると, 式 (3) の関係はフィルターの線形性を 利用して次のように周波数領域で表わされる.

$$
G_{n}(\omega)=F_{0}(\omega) \cdot H_{n}(\omega)
$$
ただし，

$$
\begin{aligned}
G_{n}(\omega) & =\int_{-\infty}^{\infty} g_{n}(t) e^{-i \omega t} d t \\
F_{0}(\omega) & =\int_{-\infty}^{\infty} f(t) e^{-i \omega t} d t
\end{aligned}
$$

したがって, 出力 $g_{n}(t)$ は式 $(18)$ をフーリエ逆変換し て次式のようにも与えられる。

$$
g_{n}(t)=\frac{1}{2 \pi} \int_{-\infty}^{\infty} F_{0}(\omega) \cdot H_{n}(\omega) e^{i \omega t} d \omega
$$

すなわち, 出力 $g_{n}(t)$ を求めるのに式 (3) のような時 間領域 (Convolution) と式 (19) のような周波数領域 (Fourier 変換) による二つの方法が考えられる. 計算 時間の点からすると, 高速フーリエ変換 (FFT) を利用 すれば式 (19) の方が格段に有利であり，この研究では 後の強震記録等の解析はすべて式 (19) による周波数領 域での計算によった.

ところで, 瞬間フーリエ・スペクトル $F(\omega, t)$ は円 振動数 $\omega$, 時間 $t$ の両変数についての解析であるので, 両者の分解精度がともに高いことが望ましい.すなわ ち, 分解精度の点からいえば, 時間領域でのインパルス 応答関数 $h_{l}(t-\tau)$ は時間 $t$ の近傍でできるだけシャー プで, かつ周波数領域でのシステム関数 $H_{n}(\omega)$ は中心 円振動数 $\omega_{n}$ のまわりでできるだけ狭帯域であることが 望ましい. しかし, 既往の研究でも明らかなようにこれ らの必要条件は互いに相反することである ${ }^{9)}$. この研究 では両者の必要条件がともに有利になる ${ }^{11)}$ 次のよらなガ ウス形システム関数を考えた。

$$
H_{n}(\omega)=e^{-\alpha\left(\omega-\omega_{n}\right)^{2}}
$$

ここに, $\alpha$ は定数 $\left(\alpha=(), \omega_{n}\right.$ は中心円振動数である.

式 (20) のシステム関数の等価低域通過フィルターの インパルス応答 $h_{l}(t)$ は次のようになる.

$$
h_{l}(t)=\frac{1}{2 \sqrt{\pi \alpha}} e^{-\frac{t^{2}}{4 \alpha}}
$$

式（20）と式（21）を比較すれば，上述の必要条件が互
いに相反し，かつ定数 $\alpha$ の選択によって支配されること がかわる. 定数 $\alpha$ の選択については亀田 ${ }^{9}$ が述べた減衰 定数 $h$ の選択 と同様にある程度まで経験的かつ妥協的 に決めざるをえない.

一方, 式 (20) のシステム関数はフィルターの帯域幅 が中心円振動数 $\omega_{n}$ の選択にかかわらず一様である. し たがって, 種々の特性が全周波数帯域にわたって一様で ある波形や比較的狭い範囲の周波数帯域での特性を問題 とする現象の解析には適していると思われるが, 表面波 の伝播モードのように高周波数領域と低周波数領域での 特性が複雑に変化し, かつ広い周波数帯域にわたって展 開する現象の解析には不適当と考えられる.このような ことから,フィルターの帯域幅を中心円振動数 $\omega_{n}$ に応 じて変化させるシステム関数を用いることも考えられ る.これについては Dziewonski ら ${ }^{4)}$ が詳しく論じてい る. 彼らは周期 3 秒から周期 120 秒にわたる長周期帯域 の地震記録解析に次のような形のシステム関数 $H_{n}(\omega)$ を用いた。

$$
H_{n}(\omega)=\left\{\begin{array}{cl}
e^{-\alpha\left(\frac{\omega-\omega_{n}}{\omega_{n}}\right)^{2}} & (1-\beta) \omega_{n} \leqq \omega \leqq(1+\beta) \omega_{n} \\
0 & \omega<(1-\beta) \omega_{n} \text { または } \\
& \omega>(1+\beta) \omega_{n}
\end{array}\right.
$$

ここに， $\alpha, \beta$ は定数であり， $\beta$ は計算時間を有利にす るために導入されたものである.

式 (22) のシステム関数はべキ項が中心円振動数 $\omega_{n}$ で規準化されており，円振動数 $\omega$ の対数表示に対して 带域幅が一様となる. 式 (22) のシステム関数の等価低 域通過フィルターのインパルス答 $h_{l}(t)$ は $\beta$ を与え ないとき次のようになる。

$$
h_{l}(t)=\frac{\omega_{n}}{2 \sqrt{\pi \alpha}} e^{-\frac{\omega_{n}^{2} \cdot t^{2}}{4 \alpha}}
$$

式 (21) と式 (23) のインパルス态答関数を比較すれば 明らかなよ5に, 式 (20) のシステム関数が時間軸 $t$ に ついての分解精度を一様にするのに対して, 式 (22) の システム関数は時間軸 $t$ の分解精度をフィルターの中心 円振動数 $\omega_{n}$ により変えることがわかる. この点, 前述 の瞬間 フーリエ・スペクトル $F(\omega, t)$ の物理的意味に 関連して式 (22) のシステム関数は工学的応用には不適 当な点もある・い-゙れにしても，式 (20)，(22）のいず れのシステム関数を用いるかも，前述の定数 $\alpha$ の選択と 同様に解析対象となる強震記録の㓮波数帯域および解析 の目的に応じて妥協的に決めざるをえない.

この研究では後に示すようにシミュレーションされた 地震記録に対して式 (20), 式 (22) の両方のシステム関 数を用い，かつ定数を種々変えて解析した結果を比較し てみたが, 周期 0.1 秒から周期 5.0 秒程度の周期帯域 で地震波動特性を論じるには式（22）のシステム関数で 
$\alpha=50, \beta=0.15$ を用いることが 分解精度, 計算時間の 両面から有利であることが知れた，そこで，以下の強震 記録の解析ではおむに式 $(22)$ の形のシステム関数を帯 域通過フィルターとして用いた。

\section{3. 強震記録の非定常スペクトル解析例とその 考察}

\section{（1） SMAC 強震記録の非定常スペクトル解析例}

上述の瞬間フーリエ・スペクトル解析をわが国で得ら れた代表的な SMAC 強震記録に適用した. 図一-4, 5 は それぞれ 1968 年十勝沖地震の際に八戸港湾で得られた $\mathrm{SMAC}$ 強震記録 ${ }^{12)}$ の $\mathrm{N}-\mathrm{S}$ 成分, $\mathrm{E}-\mathrm{W}$ 成分の非定常ス ペクトル特性を周期，時間の両変数にわたって求めた結 果である. 両図は周期，時間の両変数にわたって計算さ れた瞬間フーリエ・スペクトルの最大值を 99 に規準化 してコンピューターに出力させた結果にコンターを付し たものである、な拉，計算は SMAC 強震記録を 0.04 秒間隔でサンプリングし，システム関数は $\alpha=50, \beta=$ 0.15 として式 (22) を用いて行った.また，まったく同
様な方法により 1973 年根室半島沖地震の際に釧路港湾 で得られた SMAC 強震記録 ${ }^{13)} の \mathrm{~N}-\mathrm{S}$ 成分, $\mathrm{E}-\mathrm{W}$ 成 分の非定常スペクトル特性を求めた結果が 図一6，7 で ある. 以下では 図一4 から 図一7 のよらに非定常スペ クトル特性を周期, 時間にわたって二次元的に表わした ものを非定常スペクトルマップとよぶことにする.

\section{（2）非定常スペクトル解析結果の地震波動伝播特性 からの解釈}

図一4 から 図一7 の非定常スペクトルマップをみると 程度の差はあるが，いずれも主要動部のスペクトルの非 定常性になんらかの規則性がみられる.すなわち，各周 期の瞬間フーリエ・スペクトルの時間的変動をたどると ピークとなる時間が周期により異なり，しかも，各周期 の局所的なスペクトルのピークをつらねたコンターに規 則的な凹凸形状がみられる，たとえば，図一5 の主要動 $30 \sim 40 \mathrm{sec}$ 付近の局所的ピークの時間的変動を例にとる と, 周期 1.2 秒のピークが時間 $35 \mathrm{sec}$ 付近にあるのに 対して周期 0.9 秒では時間 $31 \mathrm{sec}$ と早くなり, さらに 短周期に移行するとピークの在する時間が再び遅くな り, 周期 0.5 秒では時間 $35 \mathrm{sec}$ 付近にピークが存す

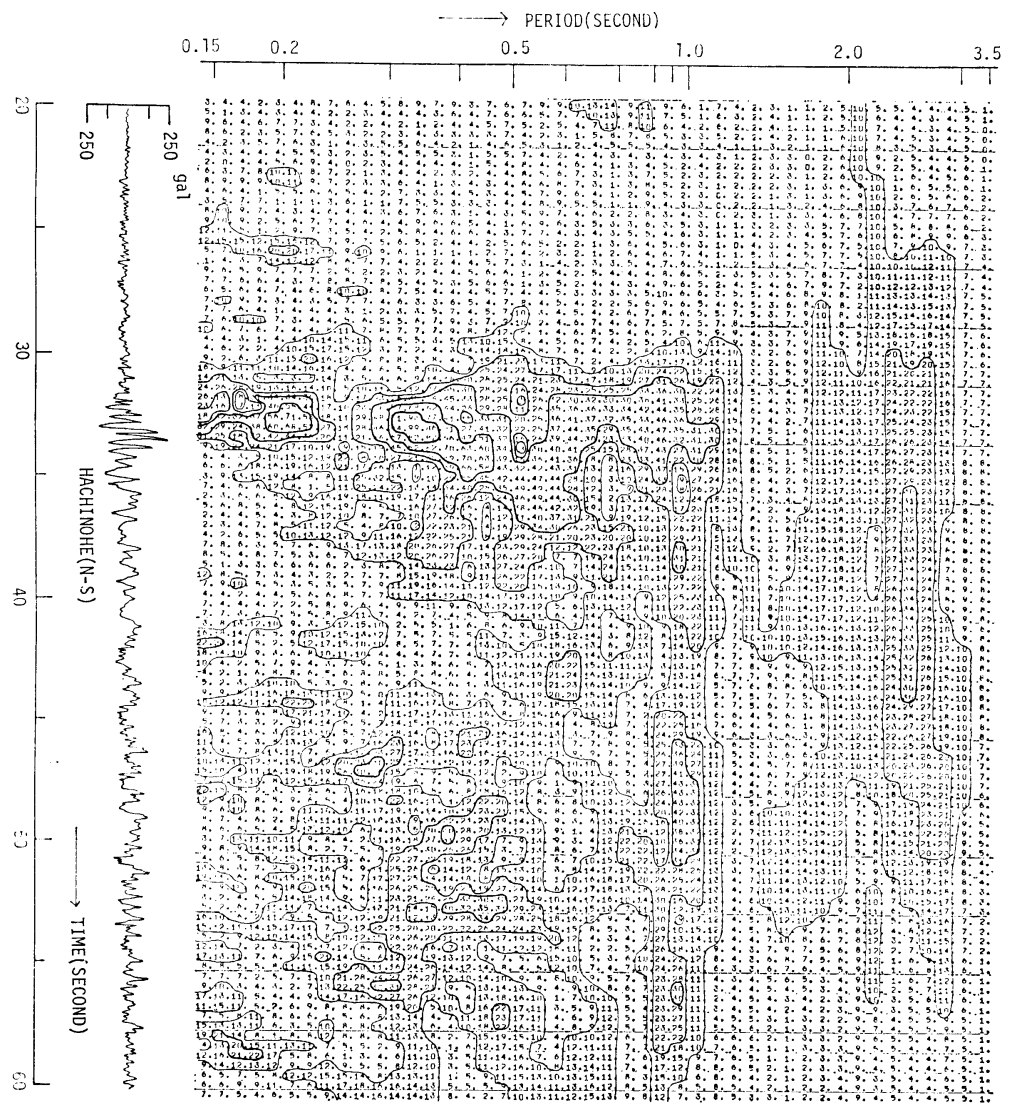

図-4 非定常スペクトル解析結果（1968 年十勝沖地监，八户港湾 SMAC 強震記録 N-S 成分） 


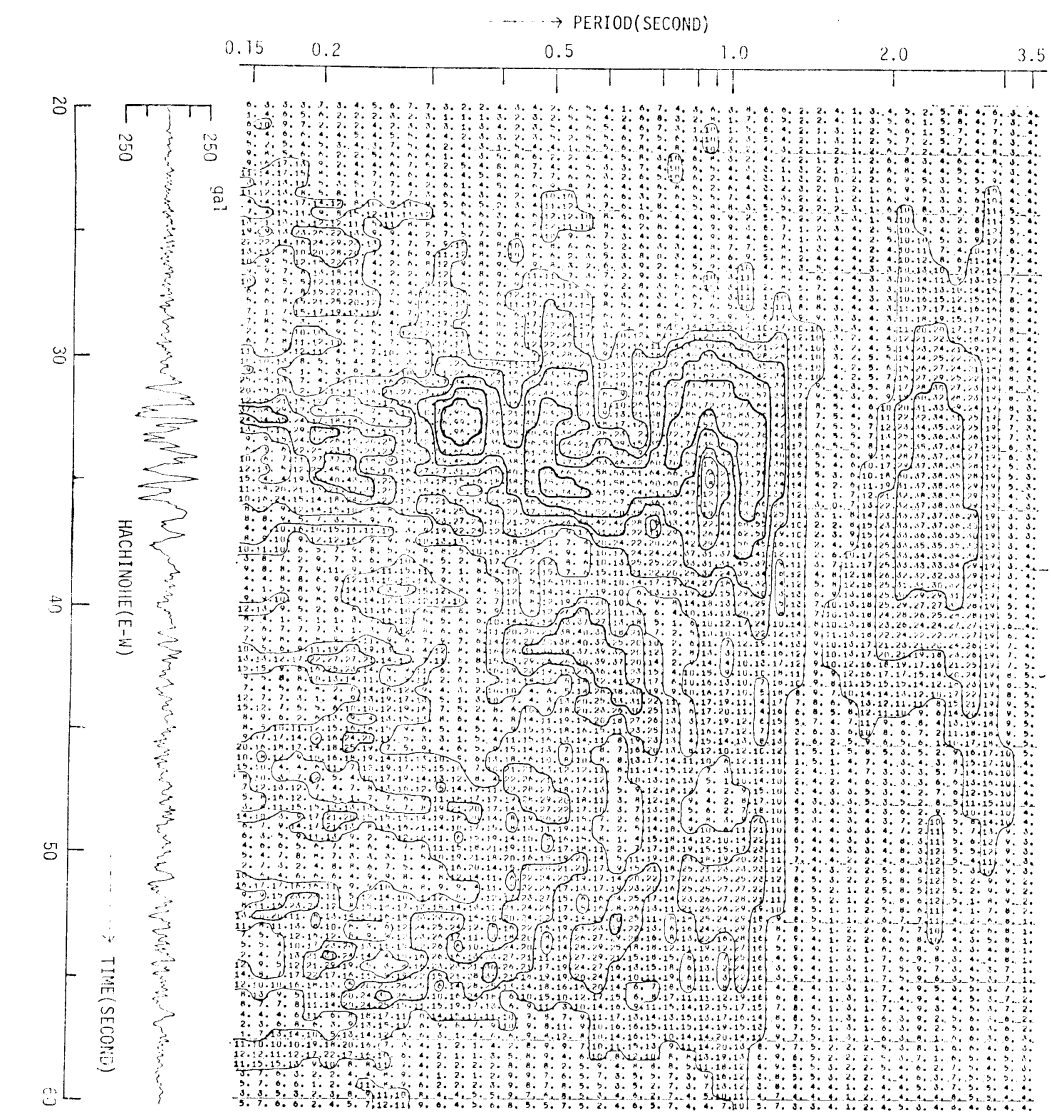

図一5 非定常スペクトル解析結果 (1968 年十勝沖地震, 八元港湾 SMAC 強震記録 $\mathrm{E}-\mathrm{W}$ 成分)

る.このような非定常スペクトルマップにおける非定常 状態の規則性に対する原因は種々考えられる．たとえ ば, 震源における地震エネルギーの放出過程, 地震波動 特性, 地盤の地震時におおる物性変化などがあげられよ 5. 事実, 強震記録の非定常スペクトル特性と震源に㧈 ける地震エネルギーの放出過程との関連を論じた研究も ある ${ }^{14)}$. しかし，ここで解析している SMAC 強震記録 はいずれも震源距離 $100 \mathrm{~km}$ 程度以上の遠方の観測点で 得られた記録であり，たとえ震源の影響があったとして も震源から観測点まで伝播する地震波動の特性や観測点 付近の地盤構造の影響が強くあらわれ，それらの影響は マスクされてしまらと考光られる。また，地盤の物性変 化に上る影響についても人射する地震波の特性や地艋構 造に大きく左右されると思われる。 そこで，以下では上 述の非定常スペクトル特性の規則性をおもに観測点付近 り地盤構造と地震波動特性の影響にしぼって考察する。

表一1は八戸港湾における PS 波速度構造を示したも のである゙2. 表一1のような速度構造に対して期待され るS 波重複反射理論, Love 波伝播, Rayleigh 波伝播の それぞれの増幅特性はすでに別論文で求めてある（文献 2)の 図-16 18). これらの理論増幅特性亡 図一4,5
表一1 八戸港湾における速度構造

\begin{tabular}{c|c|c|c|c}
\hline $\begin{array}{c}\text { Depth } \\
(\mathrm{m})\end{array}$ & $\begin{array}{c}\text { Thickness } \\
(\mathrm{m})\end{array}$ & $\begin{array}{c}\text { S-wave } \\
\text { velocity } \\
(\mathrm{m} / \mathrm{sec})\end{array}$ & $\begin{array}{c}\text { P-wave } \\
\text { velocity } \\
(\mathrm{m} / \mathrm{sec})\end{array}$ & $\begin{array}{c}\text { Density } \\
\left(\mathrm{g} / \mathrm{cm}^{8}\right)\end{array}$ \\
\hline 2.0 & 2.0 & 100.0 & 250.0 & 1.8 \\
4.0 & 2.0 & 160.0 & 860.0 & 1.8 \\
7.0 & 3.0 & 195.0 & 860.0 & 1.9 \\
10.0 & 3.0 & 195.0 & 1660.0 & 2.0 \\
12.0 & 2.0 & 380.0 & 1660.0 & 2.0 \\
13.0 & 1.0 & 200.0 & 1660.0 & 2.0 \\
14.0 & 1.0 & 375.0 & 1660.0 & 2.0 \\
17.0 & 3.0 & 375.0 & 1900.0 & 1.6 \\
18.0 & 1.0 & 200.0 & 1900.0 & 1.6 \\
28.0 & 10.0 & 430.0 & 1900.0 & 1.6 \\
36.0 & 8.0 & 270.0 & 1900.0 & 1.7 \\
180.0 & 144.0 & 370.0 & 1900.0 & 1.9 \\
360.0 & 180.0 & 690.0 & 2060.0 & 2.0 \\
380.0 & 20.0 & 1100.0 & 2600.0 & 2.1 \\
& & 2800.0 & 4990.0 & 2.5 \\
\hline
\end{tabular}

の八戸港湾での SMAC 強震記録の解析結果の振幅特性 とを比較すると，振幅が卓越する周期がよく一致してお り，ここで議論している八户港湾での SMAC 強震記録 が観測点付近の地盤構造の影響を受けていることはほぼ 確実であると思われる．しかし，いずれの理論の比較が もっとも一致しているかは増幅特性の比較だけでは明確 でない，したがって，これらの強震記録にみられる波動 


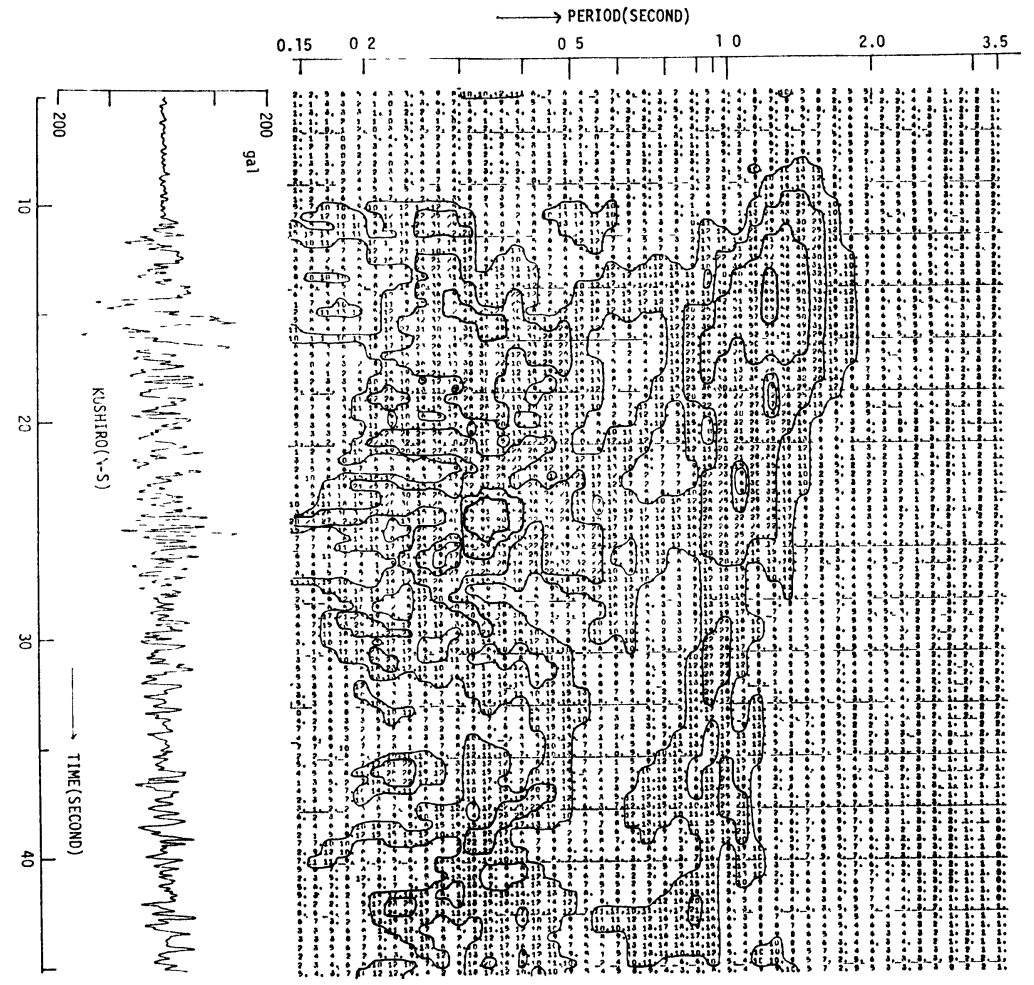

図一6 非定常スペクトル解析結果 (1973 年根室半島沖地震, 釧路港湾 SMAC 強震記録 N-S 成分)

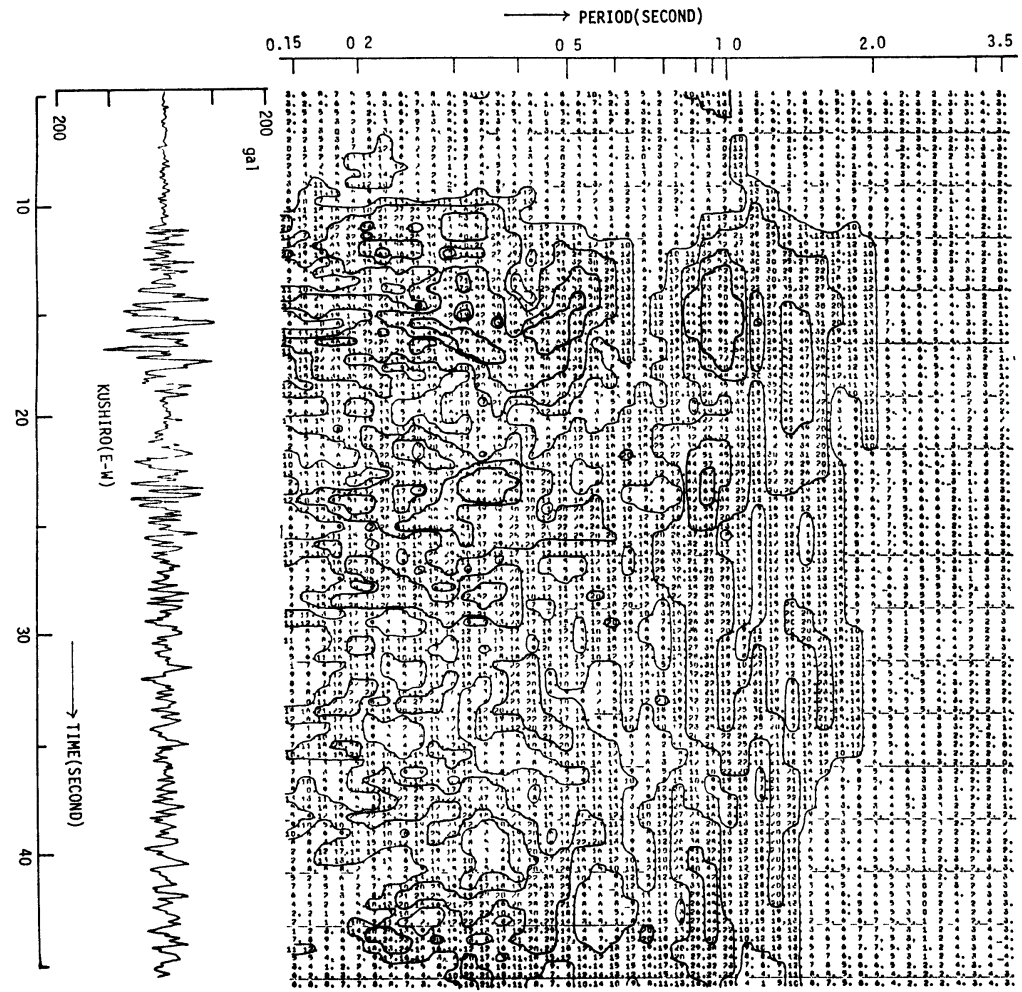


特性をみきわめるには各周期の振幅特性の時間的変動を 問題にする必要がある.

ところで, 図一4，5 のような非定常スペクトルマッ プにみられる各周期の瞬間フーリエ・スペクトル振幅の ピークとなる時間が一定の規則に従い, 異なる現象は波 動論的考察に限ると分散性に帰因寸ると考えるのが妥当 であろう， $\mathrm{P}$ 波， $\mathrm{S}$ 波のような実体波には分散性は考え られないから，ここで議論している SMAC 強震記録の 主要動は分散性の性質をもつ表面波 (Love 波, Rayleigh 波）の特性が強いと予想される。図一8，9 はそれぞれ 表一1の地盤構造が水平力向に無限に連続しているとし た場合の Love 波, Rayleigh 波の群速度分散を高次モ 一ドまで求めた結果である.一般に表面波のエネルギー は群速度で伝播することが知られているので, 八戸港湾 での SMAC 強震記録の主要動に表面波の特性が強いと すれば，図一4，5の非定常スペクトルマップの主要動 部の規則性と 図一8，9 の群速度の分散特性の相関は強 いと考えられる.しかし，これを厳密に考察するには困

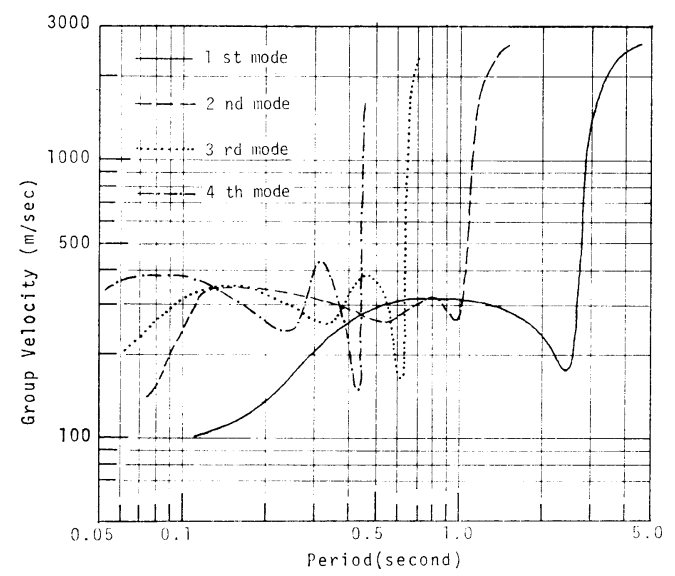

図-8 Love 波群速度分散曲線 (八下港沙)

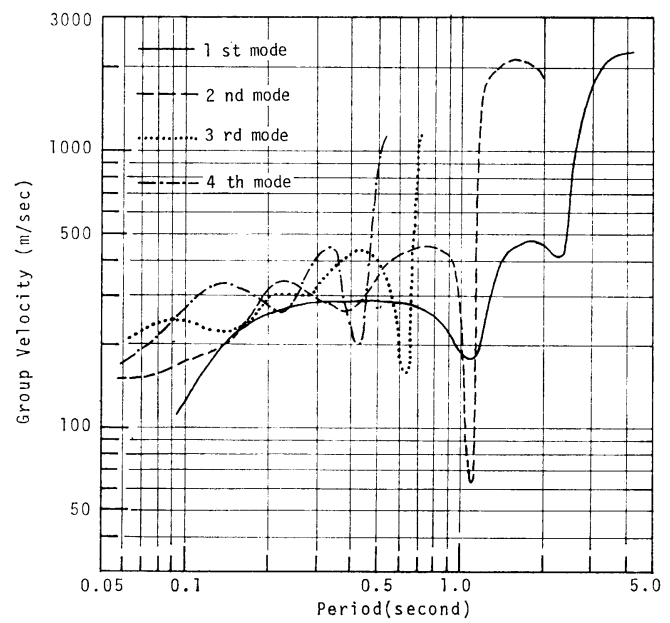

図一9 Rayleigh 波群速度分散曲線（八戸港湾）

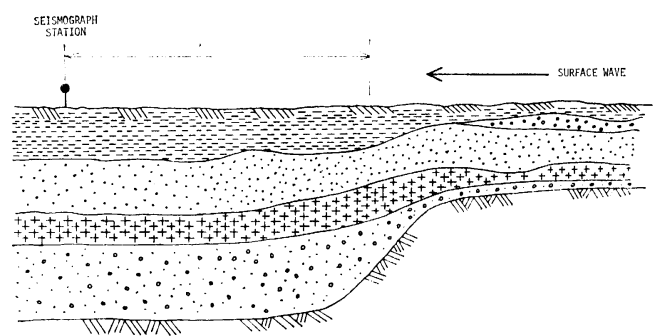

図一10地盤構造不連続部の模式図

難が多い，一つには，ここで考えている地盤構造の表 面波伝播方向での 連続性が末知であること，二つには SMAC 強震記録の時間軸が発震時の時間から絶対的に 測られたものでないこと, 三つには地震波の伝播方向が 震源域の移動 ${ }^{15)}$ といまって明瞭でないことなどがあげ られる.そこで, 以下ではいくつかの仮定を設けて上述 の相関を考察する.

1968 年十勝沖地震の震源域は八戸のほぼ真東の約 60 〜 $180 \mathrm{~km}$ にあるとされているが15), このような長い距 離にわたって表一1の地盤構造が八戸港湾の観測点から 震源域まで連続しているとは考えられず, なんらかの不 連続が存在するものと思われる.しかし，この地盤構造 の不連続の形態については先に述べたように明らかでな いので，いま仮に日本の沖積平野によくみられる地下断 層を想定して，図一10 の模式図に示すように 表一1の 地盤構造が観測点から震源方向にむかってある距離 $\Delta$ まで連続していると仮定する，さらに，震源域からなん らかの影響で生じた表面波が観測点方向に伝播する過程 において,この不連続部の距離 $\Delta$ より図一8,9 の分散 関係が生じ，これが観測点での強震記録に現われると仮 定する. すると, 距離 $\Delta$ を図一8，9 の群速度で除す ることにより各モードの表面波が観測点に到達する相対 的な到達時間は求めることができる．ただし，4の大き さは未知であり，また先に述べたように SMAC 強震記 録の時間軸は発震時からの絶対的な時間でなく，したが って, $\Delta$ の大きさを仮定して求まる各モードの表面波の 到達時間を 図-4,5 の非定常スペクトルマップに対応 させる時間的規準はない.このようにムの大きさにつ いても, また, 時間的基準についても未知なので, ここ では種々の $\Delta$ の大きと時間的基準を仮定して計算を 繰り返した. そして, 各周期の表面波の到達時間をつら ねた到達時間曲線と図一4，5 の非定常スペクトルマッ プとを比較し，もっとも合致すると思われる到達時間曲 線を求めた. 図一11，12 はこのうち $\Delta=2 \mathrm{~km}$ として求 めた Love 波, Rayleigh 波の各モードの到達時間曲線 を図-4,5 の非定常スペクトルマップにそれぞれ重ねて プロットしたものである.ここに，重ね合わせの時間的 基準は繰り返し試行の結果として $200 \mathrm{~m} / \mathrm{sec}$ の速度の表 

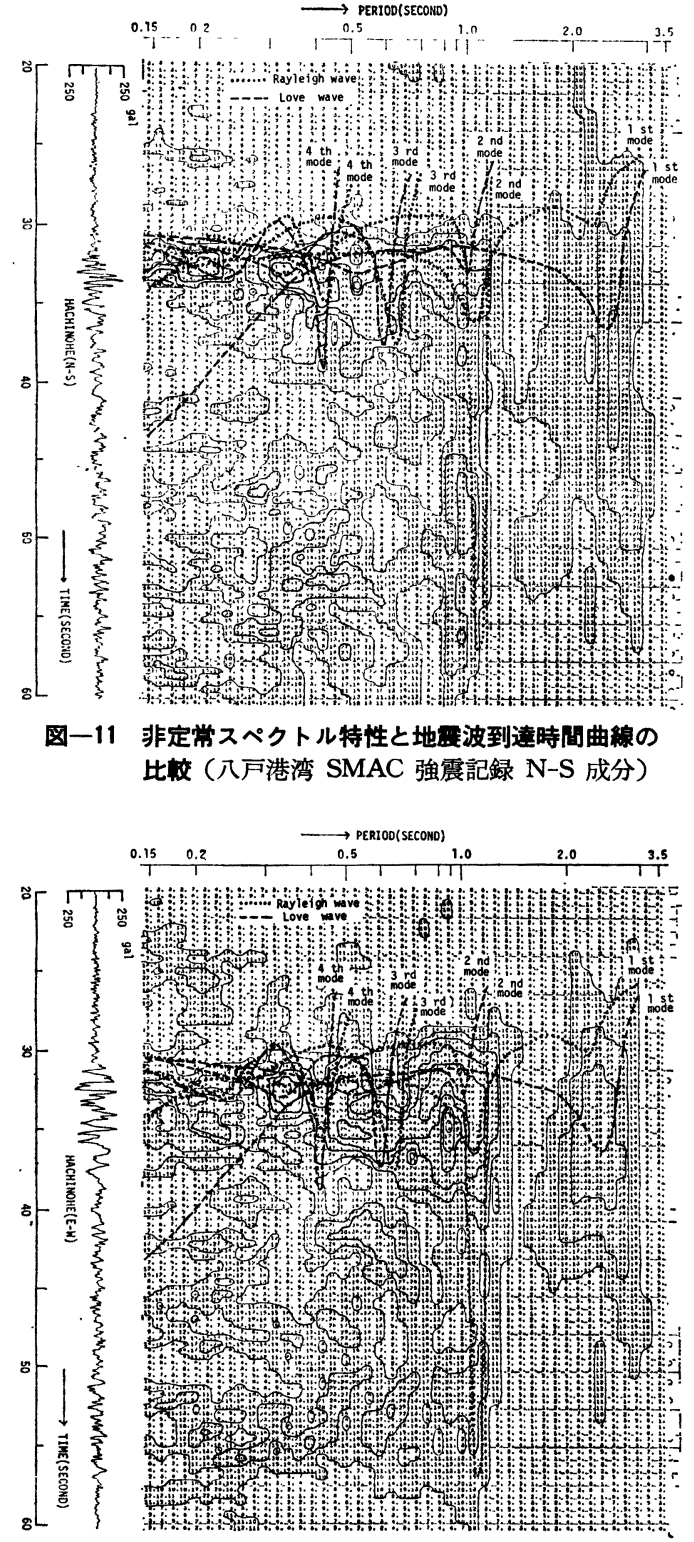

図一12 非定常スペクトル特性と地震波到遠時間曲線の 比乘 (八戸港湾 SMAC 强震記録 $\mathrm{E}-\mathrm{W}$ 成分)

面波が時間 $35 \mathrm{sec}$ に観測点に到達したとの仮定に基づい ている. $\Delta$ の大きさ, 時間的基準の仮定に問題が残ろう が，図一11，12 をみると，単純な解釈を試みたわりには 非定常スペクトルマップの主要部（時間約 30 秒から 40 秒)のコンターの凹凸形状の規則性は Love 波, Rayleigh 波の分散の合成により比較的よく説明されると思われ る. 一方，図一6，7 の釧路港湾における強震記録の解 析結果にも同様の解釈を試みたが，これも上述のような 解釈で非定常スペクトルマップの規則性がよく説明され $3^{16)}$. したがって，以上の上うな考察結果を考えると， これらの強震記録の主要動は Love 波, Rayleigh 波の
混在した表面波によるものが強いと考えてまちがいはな さそうである.もちろん，ここでの考察はあくまでいく つかの仮定を設けており，さらに詳しい厳密な考察が必 要とされる. 特に, 実際の地盤構造の水平方向不連続を 考えた定量的考察, Love 波成分と Rayleigh 波成分の 識別などさらに検討を要しよう。これらについては多く のデータと詳細な理論計算を必要とするので改めて論ず ることとする. この論文ではその予備考察として, ここ で述べた解釈の基本的な妥当性, すなわち表面波が地盤 構造不連続部を伝播することにより非定常スペクトルに 規則性が現われるとの解釈の妥当性をモデル地盤におけ る Love 波伝播のシミュレーション計算により検証す る.

\section{4. 強哑記録にみられる非定常スペクトル特性 の波動論的シミュレーション}

\section{（1）地盤構造急变部における表面波の伝播}

前章で述べたよらに表面波伝播方向での地盤構造不連 続は表面波の挙動に大きな影響を及ぼすと考えられる. 特に，わが国の沖積地盤は地下の段丘，断層など複雑な 地質構成を多く有するので, 今後, 表面波の工学的位置 付けとともに地盤の水平方向の構成と形状は耐震工学的 にも重要視されてくると思われる.

ところで 図一10 に模式的に示した地盤構造不連続を 簃密に考慮して表面波伝播を論じるには有限要素法など が考えられる ${ }^{17)}$. しかし，有限要素法によると不連続点 から遠方の点での挙動や不規則波の時間的応答を求める には計算機の容量, 計算時間から拘束が多い.このよう なことから，図一10 に示す模式的な地盤構造不連続を 図一13 のように成層地盤 が 鉛直不連続面で接する地盤 構成に単純化することも考えられる.モデル自体は単純 であるが，適用範囲に注意すればこのようなモデルであ

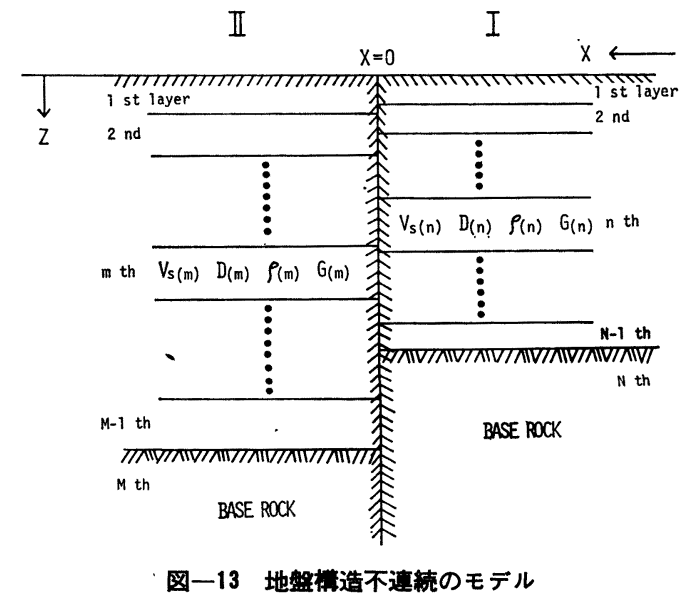


っても現実の地盤構成不連続を十分再現できると思われ るし，不連続部を含めた広い範囲の領域での不規則波の 伝播を扱える利点がある.そこで，この研究では図一13 のような地盤構成不連続部での Love 波の伝播問題につ いて考えることにする.

図一13 のようなモデルに拉ける表面波伝播の問題は 地震学の分野で多く論じられている. 特に Alsop ${ }^{18)}$ は 阁有值問題として Love 波の素波の伝播問題を巧みに考 察している．また，土岐ら ${ }^{19)}$ \& Alsop の方法を援用し て Love 波型の波動の不規則応答を求めている.ただ し，土岐らの研究では 鉛直不連続面での入射波と透過 波，反射波のエネルギー収支をはかるために基盤に剛な 半無限層を設定していわばみかけの Love 波を考えてい る.この研究では前章で述べた解釈の妥当性を判断する ことを第一義として純粋な表面波（Love 波）を扱うた め Alsop の方法を準用することにする.したがって， 以下の計算では基盤に特別に剛な半無限層を設定しない で，エネルギー収支については近似的に満足させてい る.

いま，図一13 を参照すると座標 $x, z$ での Love 波 の $p$ モードの変位 $u(t, x, z)$ のフーリエ変換 $U(\omega, x$, z) は次のように表わされる.

$$
U(\omega, x, z)=A_{p} \cdot \phi_{p}(\omega, z) \exp \left( \pm i k_{p} x\right) \cdots(24)
$$

ここに, $A_{p}$ は $p$ モードの振幅係数, $\phi_{p}$ は $p$ モード の振動形 (固有関数)， $k_{p}$ は $p$ モードの波数， $\omega$ は円 振動数.

図一13 において媒質 I 側から地盤表面で単位の振幅 をもつL Love 波の $p$ モードが入射すると, 鉛直不連続 面で反射，透過が生じ，媒質 I，II の変位のフーリエ成 分はモードの重ね合わせとしてそれぞれ次のように表わ される。

$$
\begin{aligned}
U^{\mathrm{I}}(\omega, x, z)= & \phi_{p}{ }^{\mathrm{I}}(\omega, z) \cdot \exp \left(-i k_{p}{ }^{\mathrm{I}} x\right) \\
& +\sum_{i=1}^{N} a_{i}(\omega) \cdot \phi_{i} \mathrm{I}(\omega, z) \cdot \exp \left(i k_{i}{ }^{\mathrm{I}} x\right)
\end{aligned}
$$

$$
\begin{aligned}
U^{\mathrm{II}}(\omega, x, z)= & \sum_{j=1}^{M} b_{j}(\omega) \cdot \phi_{j}{ }_{j} \mathrm{I}(\omega, z) \\
& \cdot \exp \left(-i k_{j}{ }^{\mathrm{I}} x\right) \ldots \ldots
\end{aligned}
$$

ここに, $a_{i}(\omega)$ は反射波の振幅係数 ( $i$ モード), $b_{j}(\omega)$ は透過波の振幅係数（ $j$ モード）を表わす．また，上添 字 I，II は媒質を表わしている.

式 (25)，(26）から鉛直不連続面内のせん断応力を求 め, $x=0$ の鉛直不連続面での変位，せん断応力の連続 の条件を考えると次式が得られる.

$$
\begin{array}{r}
\phi_{p} \mathrm{I}(\omega, z)+\sum_{i=1}^{N} a_{i}(\omega) \cdot \phi_{i} \mathrm{I}(\omega, z) \\
=\sum_{j=1}^{M} b_{j}(\omega) \cdot \phi_{j} \mathrm{II}(\omega, z) \cdots \cdots . .
\end{array}
$$

$$
\begin{aligned}
& G^{\mathrm{I}}(z) \cdot k_{p}{ }^{\mathrm{I}} \cdot \phi_{p} \mathrm{I}(\omega, z)-G^{\mathrm{I}}(z) \\
& \quad \cdot \sum_{i=1}^{N} a_{i}(\omega) \cdot k_{i}{ }^{\mathrm{I}} \cdot \phi_{i} \mathrm{I}(\omega, z) \\
& \quad=G^{\mathrm{I}}(z) \cdot \sum_{j=1}^{M} b_{j}(\omega) \cdot k_{j} \mathrm{I} \cdot \phi_{j} \mathrm{I}(\omega, z)
\end{aligned}
$$

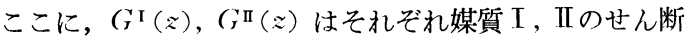
弾性係数.

式（27），(28）を連立させてもモード間の連成により $a_{i}(\omega), b_{j}(\omega)$ などの係数は厳密には解けない. しかし， Love 波の振動形 $\phi_{i}{ }^{\mathrm{I}}(\omega, z)$ などにはせん断弾性係数 $G^{\mathrm{I}}(z)$ を重み関数として次式のような関係で直交化す る性質がある ${ }^{18)}$.

$$
\begin{array}{r}
\int_{0}^{\infty} \phi_{i}{ }^{\mathrm{I}}(\omega, z) \cdot \phi_{j}{ }^{\mathrm{I}}(\omega, z) \cdot\left({ }^{\mathrm{I}}(z) d z=0(i \succ j)\right. \\
\ldots \ldots \ldots \ldots \ldots \ldots \ldots \ldots(29) \\
\left.\int_{0}^{\infty} \phi_{i}{ }^{\mathrm{II}}(\omega, z) \cdot \phi_{j}{ }^{\mathrm{I}}(\omega), z\right) \cdot G^{\mathrm{I}}(z) d z=0(i \neq j)
\end{array}
$$

したがって，これらの性質を利用することにより鉛直不 連続面での変位の 2 乗の差を最小にする最適化の手法を 適用して係数 $a_{i}(\omega), b_{j}(\omega)$ を数值的に求めることがで きる. 寸ると, 鉛直不連続面 $x=0$ 一媒質 I 側から任意 の $p$ モードの不規則波形 $f(t)$ なる Love 波が入射し たときの反射 Love 波, 透過 Love 波の時間応答 $u^{1}$ $(t, x, z), u^{\mathrm{II}}(t, x, z)$ はそれぞれ次のように求まる.

$$
\begin{aligned}
& u^{\mathrm{I}}(t, x, z)=\frac{1}{2 \pi} \int_{-\infty}^{\infty}\left\{\sum_{i=1}^{N} a_{i}(\omega) \cdot \phi_{i} \mathrm{I}(\omega, z) \cdot e^{i k_{i} x}\right\} \\
& \cdot F(\omega) \cdot e^{i \omega t} \cdot d \omega \\
& u^{\mathrm{I}}(t, x, z)=\frac{1}{2 \pi} \int_{-\infty}^{\infty}\left\{\sum_{j=1}^{M} b_{j}(\omega) \cdot \phi_{j}{ }_{j} \mathrm{I}(\omega, z) \cdot e^{-i k_{j} x}\right\} \\
& \cdot F(\omega) \cdot e^{i \omega t} \cdot d \omega
\end{aligned}
$$

ここに,

$$
F(\omega)=\int_{-\infty}^{\infty} f(t) e^{-i \omega t} d t
$$

上式の関係は変位応答に対して導いたものであるが，そ のまま速度応答や加速度応答に適用することができる.

\section{（2）モデル地盤における Love 波伝播の シミュレ ーション計算例}

この研究では実際の Love 波伝播のシミュレーション 計算を 図一14 のような表面層 1 層構造のモデルについ て行った．計算モードは媒質 I 側に基本モードの Love 波が入射し, 媒質 I 側, 媒質II側への反射 Love 波, 透 過 Love 波はそれぞれ第 5 次モードまで生じるものと した。 また，図一14のような地盤構成では軟弱な地盤 すなわち媒質Iでの表面波の挙動が重要と考え, おもに 媒質II側における透過 Love 波の応答計算を行った.

図一15 は入射 Love 波の振幅係数を 1 とした場合の透 過 Love 波の振幅係数 $b_{j}(\omega)$ を第 5 次モードまで求め 


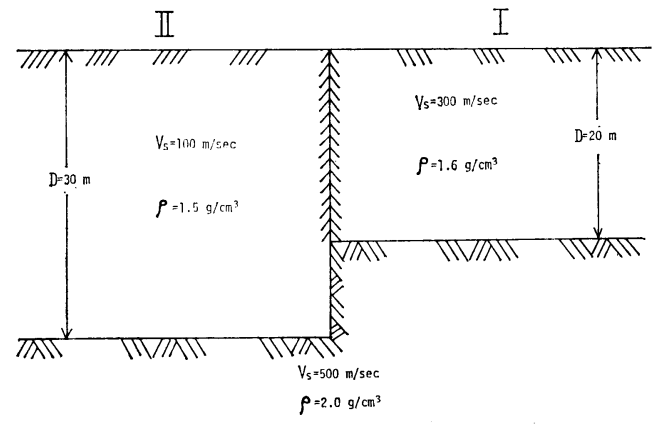

BASE ROCX

図一14 計算モデル $\left(V_{s}: \mathrm{S}\right.$ 波速度, $D:$ 層厚, $\rho:$ 密度 $)$

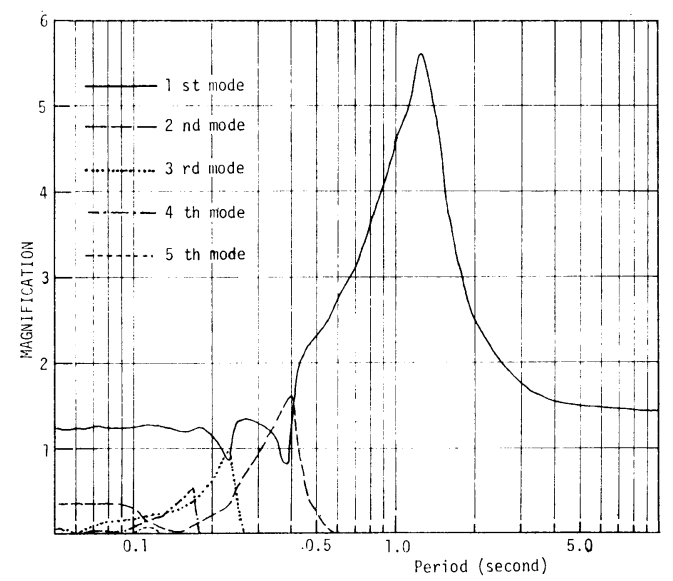

図-15 透過 Love 波の振幅係数 $b_{j}(\omega)$ の計算結果

た結果である.これはいわば媒質Ｉから媒質II - Love 波が伝播する 場合の増幅率である. 図一15 をみると， 第 1 次モード（基本モード）が大きく増幅され, 高次モ 一ドはあまり増幅されないことがわかる．また，各モー ドの増幅率がピークとなる周期は $\mathrm{S}$ 波重複反射理論によ る卓越周期

$$
T_{n}=\frac{4 H}{(2 n-1) \cdot V_{s}}
$$

ここに,

$H$ : 表面層の厚さ, $V_{s}$ : 表面層の $\mathrm{S}$ 波速度, $n:$ 正の整数

とほとんど一致することがわかる，一般に，入射側地盤 に比し透過側地盤が軟弱な場合, 振幅が大きく増幅され るとともに，第 1 次 モードの勢力が強くなるようであ る.このことは耐震工学的にはきわめて重要なことを意 味するが, ここではふれない。

一方, 図一14 における 媒質II 透過側地盤が左右に 無限に連続しているとすると，このような地盤を伝播す る Love 波の位相速度分散, 群速度分散は求めることが できる. 図一16 はこのうち群速度分散曲線を Haskell ${ }^{20)}$ の方法により求めたものである. 図一15 と図一16を比
較すると増幅率が極大となる周期は群速度が極小となる 周期とほとんど一致することがわかる. 従来より表面波 が伝播する場合, 群速度極小となる周期で振幅が卓越す ることは指摘されているが21)，ここで考えている地盤構 成不連続を伝播する表面波にもそのことがあてはまるこ とがわかる。

次に, 上述のように求めた透過 Love 波の振幅係数 $b_{j}(\omega)$ を式 (32) に適用し，媒質 II側の代表的地点にお ける透過 Love 波の加速度応答記録を求めた. その際, 鉛直不連続面に入射する入射 Love 波の加速度記録が問 題となるが，ここでは入射側地盤（媒質 I）の固有周期 (約 0.27 秒) に近い卓越周期をもつ SMAC 強震記録 (1968 年東松山地震における Kenken Training Center

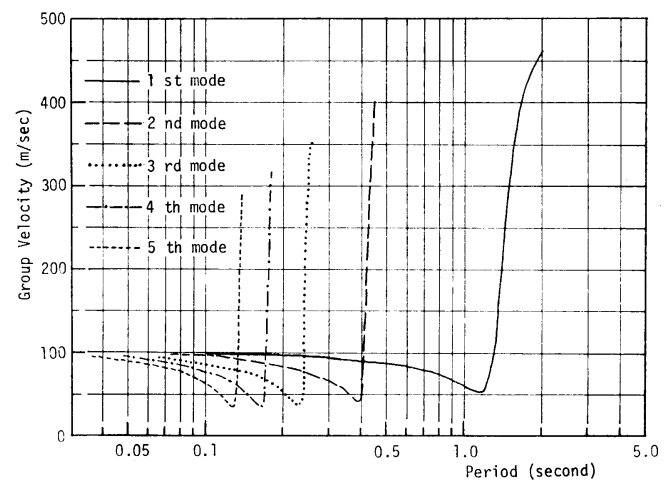

図-16 Love 波群速度分散曲線

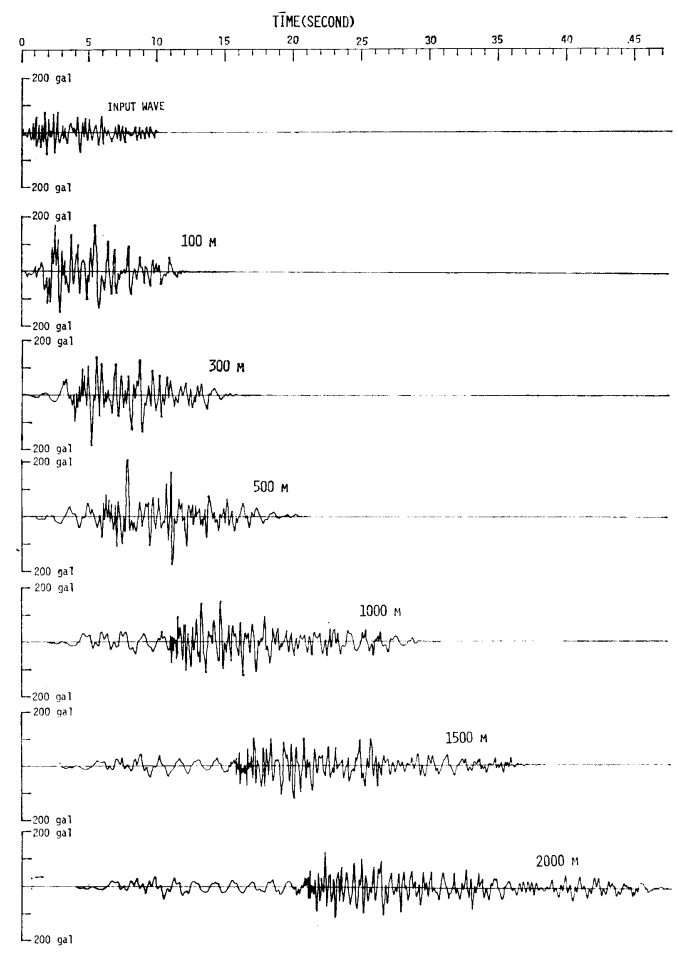

図一17 入射 Love 波と透過 Love 波の加速度記録 
での N-S 成分 ${ }^{22)}$ ）を用いた. 図一17 は代表的地点の地 表において求めた加速度記録を鉛直不連続面への入射波 とともに示したものである.なお，図一17 の各記録の 上の数字は鉛直不連続面からの 距離を表わす. 図一17 をみると全体に透過 Love 波の加速度記録は振幅が入射 Love 波に比し大きく増幅されるとともに，不連続面か ら離れるに従い, 表面波固有の分散効果により波形が複 雑に変形される様子が観察される. また, 加速度振幅は 不連続面から 距離 $500 \mathrm{~m}$ の地点で最大 (210 ガ ル）を示すなど Love 波が地盤構成不連続部付近 で特異な挙動を示すこともわかる.

\section{（3）シミュレーション計算結果の非定常スペ クトル解析とその波動論的検証}

前述のような地盤構成不連続部を伝播する Love 波のシミュレーション計算結果に 2. で述 べた非定常スペクトル解析を施した. 図一18 20 はそれぞれ，不連続面からの距離 $500 \mathrm{~m}, 1000 \mathrm{~m}$, $1500 \mathrm{~m}$ の加速度記録の非定常スペクトルマップ を求めたものである.ただし, それらの図の解析 は $\alpha=50, \beta=0.15$ として式 (22) のシステム関 数を用いて行った。 また, 図中の点線は後述のも のである.

これらの図をみると，各周期の瞬閒フーリェ・ スペクトル振幅の相対的大きさが複雑に変化して おり, 地盤構造不連続面透過による増幅特性のみ ならず，入射波の振幅特性により透過 Love 波の 振幅特性がかなり支配されることがわかる。これ は当然の帰結であるが，今後，震源過程を考慮し て表面波の伝播を考える際の一つの示唆となろ う、いいかえれば，たとえ震源から遠方の強震記 録であっても観測点付近の地盤構成の厳密な調査 と非定常スペクトルの振幅特性の詳細な検討を行 えば，ある程度まで震源過程を議論できると思わ れる。

上述の上うな振幅特性はともかく，図一18２0 の非定常スペクトルマップをみると SMAC 強震 記録の非定常スペクトルマップで認められたと同 様な非定常状態の規則性が明瞭に観察される. 特 に，図一6 と図一19を比較すると，1.0 1.5 秒の周期範囲のコンターがそれぞれ 時間 10〜20 sec, 時間 0〜20 sec にかけて, 時間経過 ととも に次第に短周期に移行するなど同一の傾向が認め られる.そこで, 次に SMAC 強震記録の非定常 性の解釈と同様の解釈，才なわち Love 波の群速 度分散によりこれらの非定常スペクトルマップの 規則性が理解されるか否かを検討した。ここでの
シミュレーション計算による加速度記録の場合，時間軸 が不連続面一入射 Love 波が到達した時刻より絶対的に 測られているので厳密な議論ができる. 図一16 の群速 度分散曲線における各モードの群速度で不連続面からの 距離を除して求めた地震波到達時間曲線をプロットした のが 図一18 から 図一20に㧍ける点線である。これら をみると,瞬間フーリエ・スペクトルの局所的ピークに先 に述べた入射 Love 波の振幅特性が強く現われていると

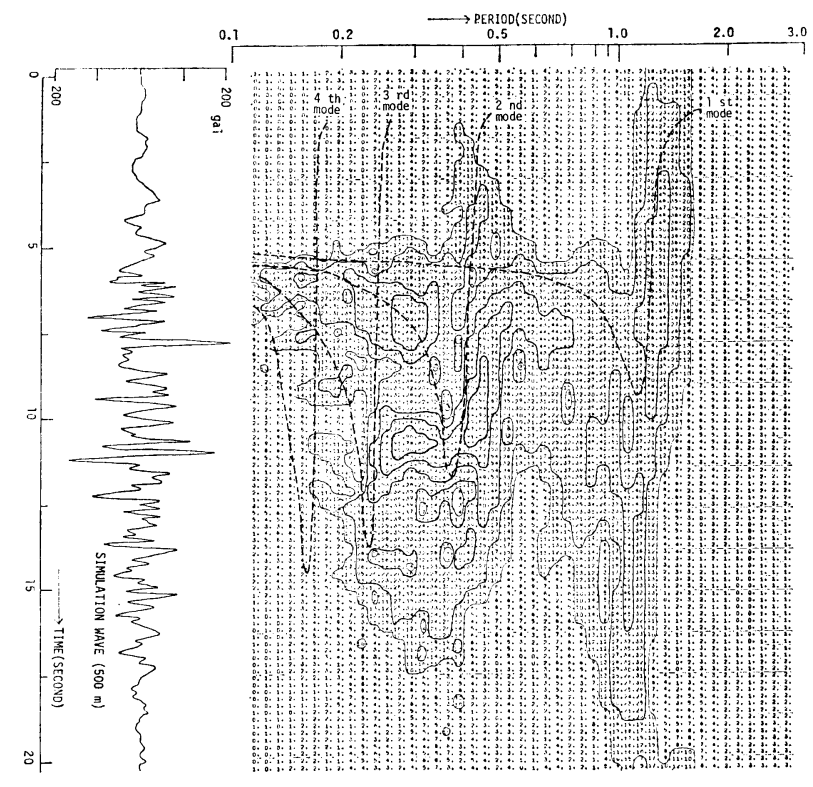

図一18 透過 Love 波加速度記録の非定常スペクトル特性 (距離 $500 \mathrm{~m}$ )

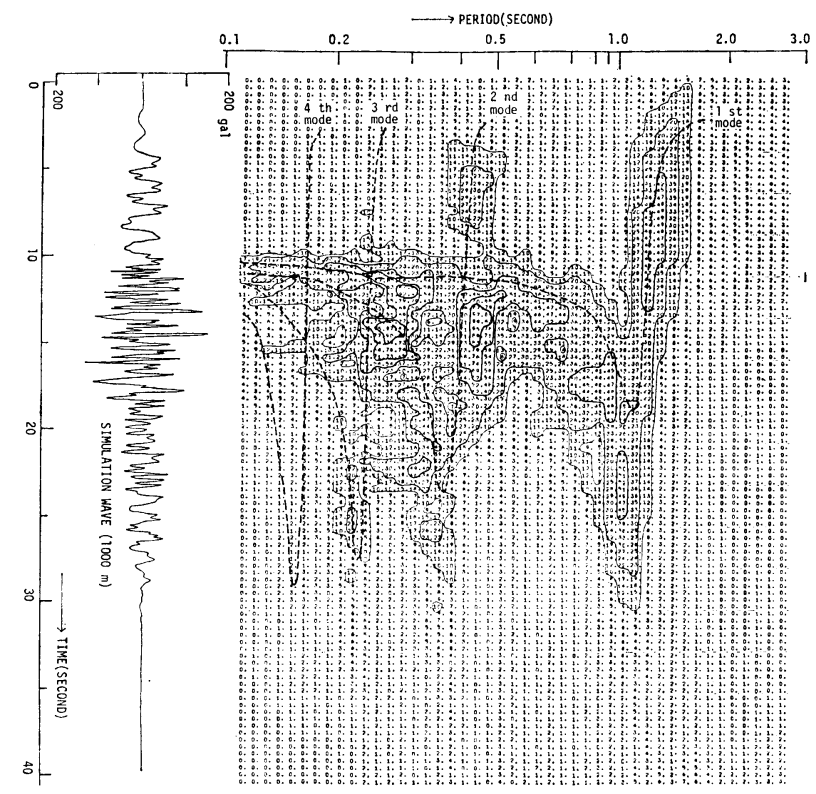

図一19 透過 Love 波加速度記録の非定常スペクトル特性 (距離 $1000 \mathrm{~m}$ ) 


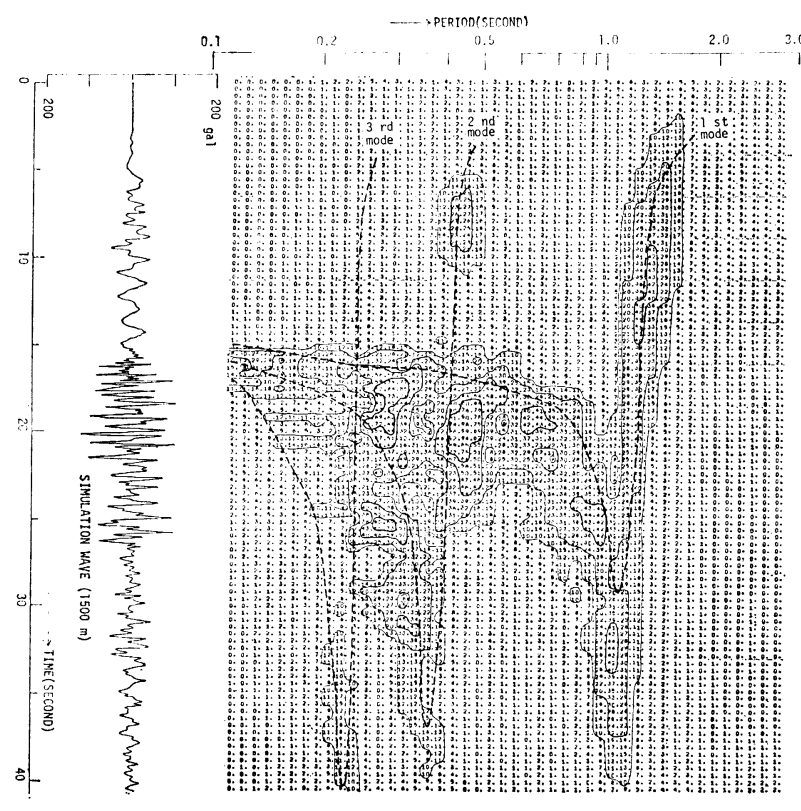

図一20 透過 Love 波加速度記録の非定常スペクトル特性 (距離 $1500 \mathrm{~m}$ )

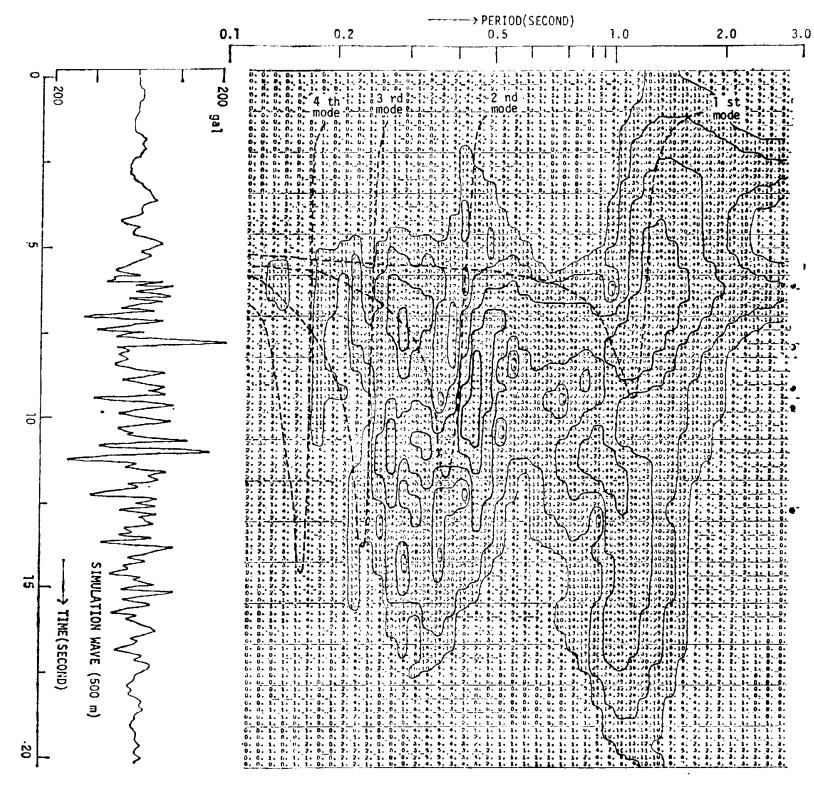

図一21 透過 Love 波加速度記録の非定常スペクトル特性

(距離 $500 \mathrm{~m}$ )ーシステム関数として式 (20) を使用一

先に導いた SMAC 強震記録の主要動が表面波で あるとの推定の確実性は，ここでほぼ裏付けられ たと考えられる.このような強震記録における表 面波の存在を考えると, 今後, 平面的ひろがりを もつ構造物の耐震設計および地盤の耐震性検討は 表面波を十分考慮に入れる必要がでてこよう.

ところで，図一17 のようなシミュレーション 加速度記録はその成因がはっきりしているので, 2. で述べた 非定常スペクトル解析のシステム関 数の選択やその定数の決定を判断するのに都合が よい.この研究では 図一17に扔ける $500 \mathrm{~m} \mathrm{の}$ 記録に式 (20), 式 (22) の両方のシステム関数 に種々の定数を設定して解析を試みた．紙面の都 合でこれらの結果をすべて示しえないが, 式 (20) のシステム関数を $\alpha=0.5$ として用いた解析結果 の例が 図一21 である. 同図中の点線は前述の地 震波到達時間曲線であるが, この代表的解析結果 をみても知れるように周期 1.0 秒以上の解析結果 がすでに述べたシステム関数の帯域幅の影響によ りあいまいである.このようなことから, 地震波 動の伝播特性の面から広い周期带域にわたって非 定常スペクトルを考察するには式 (22) のシステ ム関数を用いるのが有利と思われる.

\section{5. むすび}

この論文では非定常スペクトル特性を解析する 一手法を述べるとともに，その解析法をわが国の 代表的な SMAC 強震記録に適用し, 地震波動特 性について考察した。これらの結果を要約すると 次のようになろう.

（1）特定の地震動の波動特性や発震機構を論 じるにはマルチ・フィルタリングの原理に基づく 非定常解析法が有効である.この論文ではマル チ・フィルタリングの原理を応用した瞬間フーリ エ・スペクトルなる量を定義した.

（2）ここで定義した瞬間フーリエ・スペクト ルはもとの地震記録にウィンドー関数をかけて漏 波した信号の非減衰 1 質点系の残留速度応答スペ 思われ，ピークとなる点と群速度極小となる点は必ずし も対応しないが, 非定常状態の規則性, 特にコンターの 規則的な形状変化がこれらの曲線で合理的に説明される ことがわかる.

以上のようなモデル地盤における表面波伝播のシミュ レーション計算結果より, 強震記録に認められる非定常 スペクトルの規則性の成因に対して仮説した波動論的解 釈の妥当性が検証されたものと思われる.したがって, クトルを尺度として非定常性を表現する物理的意味をも ว.

（3）瞬間フーリエ・スペクトルを解析する際の帯域 通過フィルターの選択についてはある程度まで経験的に 行ら必要がある.ただし, 周波数領域, 時間領域の両領 域に対する分解精度を良好にする帯域通過フィルターは ガウス形であり，特に，地震波動特性の考察などの目的 に対して広い周波数領域にわたる解析には式 (22) のシ 
ステム関数を $\alpha=50, \beta=0.15$ として用いるのが, 分解 精度, 計算時間の両面から有利である.

（4）代表的な SMAC 強震記録の非定常スペクトル 解析結果をみると, ともに主要動部分のスペクトルの非 定常状態に規則性が観察される.

（5）これらの規則性を表面波の分散現象に起因する との観点から, 強震記録観測点の地盤構造を考慮した理 論計算により検討した結果，Love 波， Rayleigh 波の 表面波の分散現象の重合によりよく説明される.

（6）上述の波動論的解釈の妥当性をモデル地盤にお ける Love 波伝播のシミュレーション計算により検証し た. その結果，表面波が地盤構造急変部を伝播する場 合, 種々の増幅, 減衰があると同時に, 表面波固有の分 散性の効果により伝播過程で波形が複雑に変化し，スペ クトルの非定常性に規則性が現われることが明らかとな った.これにより，SMAC 強震記録の非定常スペクト ル特性に適用した波動論的解釈の妥当性がほぼ確認され た.

（7）このような強震記録における表面波の存在を考 えると, 表面波を取り入れた耐震設計を急ぐべきと思わ れる。

この論文では SMAC 強震記録の波動論的考察に関し て地盤の水平方向構造にいくつかの仮定を設けた.さら に強震記録のなかの 鉛直動成分の特性も含めた Love 波, Rayleigh 波の分離, 識別の問題にもふれなかった. これらについては現実の地盤構造に即した厳密な考察と 震源特性を問題にする必要があるので，機会を改めて報 告したい. また，今回は代表的な強震記録のみを例にと り波動特性を論じたが，地震波動は地震の種々の条件 （マグニチュード，震源距離，震源梁さなど）により特 性が変ると予想されるので, さらに総合的な検討が必要 である.これについては今後の課題としたい.

この論文では運輸省港湾技術研究所で提供されている SMAC 強震記録を利用させていただいた．日頃，貴重 な資料を提供されている港湾技術研究所の皆様に感謝い たします.

なお, 本研究の一部は昭和 50 年度文部省科学研究費 補助金 (奨励研究 A) によったこと, 本研究における数 值計算は東北工業大学計算センターの TŌSBAC 340041 を用いたことを付記する.

\section{参 考 文 献}

1）神山 真：強震記録の波動論的考察, 土木学会第 13 回地 震工学研究発表会講演概要, pp. 41 44, 1974.

2）神山 其：地震時における地盤内の応力，ひずみの評価，
土木学会論文報告集，第 250 号. pp. 9～23，1976.

3）日野幹雄 : スペクトル解析, 朝倉書店, 1977.

4) Dziewonski, A., S. Bloch and M. Landisman : A technique for the analysis of transient seismic signals, Bull. Seis. Soc. Am., Vol. 59, No. 1, pp. 343 356, 1971.

5) Trifunac, M.D. : Response envelope spectrum and interpretation of strong earthquake ground motion, Bull. Seis. Soc. Am., Vol. 61, No. 2, pp. 343 356, 1971.

6）土岐憲三：強震加速度記録による位相速度の検出，第 4 回日本地震工学シンポジウム講演集, pp. 265〜272, 1975.

7) Priestley, M.B.:Power spectra and non-stationary process, Jour. of R. Stat. Soc. B, 27, pp. 204 237, 1965.

8) Mark, W.D. : Spectral analysis of the convolution and filtering of non-stationary stochastic processes, Jour. of Sound and Vibr., Vol. 11, No. 1, 1970.

9）亀田弘行 : 強震地震動の非定常パワースペクトルの算出 法に関する一考察, 土木学会論文報告集, 第 235 号, pp. $55 \sim 62,1975$.

10）星谷 勝・ 千葉利晃 - 草野直幹 : 地震加速度波の非定常 特性とシミュレーション，士木学会論文報告集，第 245 号, pp. 51 58, 1976.

11) Papoulis, A. : The Fourier Integral and Its Application, McGraw-Hill, 1962.

12) Tsuchida, H., E. Kurata and K. Sudo : Strong-Motion Earthquake Records on the 1968 Tokachi-Oki Earthquake and Its After Shocks, Technical Note of the Port and Harbour Res. Inst., No. 80, 1969.

13）倉田栄一・石坂徳三 - 士田 肇 : 港湾地域強震観測年報 (1973)，港湾技研資料，No. 181，1974.

14) Trifunac, M.D. and J.N. Brune : Complexity of energy release during the Imperial Valley, California, earthquake of 1940, Bull. Seism. Soc. Am., Vol. 60, pp. $137 \sim 160,1970$.

15）村松郁栄 : 1968 年十勝沖地震の地震動, 文部省科学研究 費「構造物災害に対与る地震動特性の研究」報告, pp. 86 106, 1972.

16）神山 真：強震記録の波動論的考察一第 3 報, 土木学会 第 31 回年次学術講演会講演概要集, 第 1 部, pp. 395 396, 1976.

17) Lysmer, J. and L.A. Drake: The propagation of Love waves across nonhorizontally layered structures, Bull. Seis. Soc. Am., Vol. 61, No. 5, pp. 1233 1251, 1971.

18) Alsop, L.E. : Transmission and reflection of Love waves at a vertical discontinuity, Jour. Geophy. Res., Vol. 71, No. 16, pp. 3969 3984, 1966.

19）土岐憲三・新田篤志 : 表面波に対する表層地盤の不規則 応答, 土木学会第 13 回地震工学研究発表会講演概要, pp. $21 \sim 24,1974$.

20) Haskell, N.A. : The dispersion of surface waves on multilayered media, Bull. Seis. Soc. Am., Vol. 42, No. 2, pp. $17 \sim 34,1953$.

21) Ewing, W.M., W.S. Jardetzky and F. Press : Elastic Waves in Layered Media, McGraw-Hill, 1957.

22) Ohsaki, Y., et. al. : Digitized Strong-Motion Earthquake Accelerograms in Japan, Gakujutsu Bunken Fukyukai, pp. $420 \sim 437,1972$.

(1978.4.7 • 受付) 